Ouachita Baptist University

Scholarly Commons@Ouachita

Articles

Faculty Publications

Winter 1996

\title{
Abortion and Harm to Children: Limits on Television Political Advertisements
}

David Ozmun

Ouachita Baptist University, ozmund@obu.edu

Follow this and additional works at: https://scholarlycommons.obu.edu/articles

Part of the Broadcast and Video Studies Commons, Mass Communication Commons, and the Public Relations and Advertising Commons

\section{Recommended Citation}

Ozmun, David, "Abortion and Harm to Children: Limits on Television Political Advertisements" (1996). Articles. 124.

https://scholarlycommons.obu.edu/articles/124

This Article is brought to you for free and open access by the Faculty Publications at Scholarly Commons @ Ouachita. It has been accepted for inclusion in Articles by an authorized administrator of Scholarly Commons @ Ouachita. For more information, please contact mortensona@obu.edu. 


\section{ABORTION AND HARM TO CHILDREN: LIMITS ON TELEVISION POLITICAL ADVERTISEMENTS}

\section{David Ozmun*}

Candidates wanting to air advertisements containing graphic depictions of aborted fetuses presented television stations with a dilemma. Sections 312(a)(7) and 315(a) of the Communications Act prevent broadcasters from censoring or restricting the political advertisements of legally qualified candidates seeking federal office. Under the United States Criminal Code, broadcasting material deemed indecent may result in penalties. Also, the Federal Communications Commission and courts have expressed concern about "harm to children" caused by televised material.

While the FCC disagreed with a district court judge's ruling that political ads containing depictions of aborted fetuses were indecent, it did affirm a broadcast licensee's right to "channel" such ads to a time of day when children are less likely to be in the audience. This provides broadcasters, for the first time, with some editorial discretion during federal election seasons. However, by not giving broadcasters control over advertising enjoyed by other media, the FCC may have encouraged candidates to further test the limits of Sections 312 and 315.

For years, the political campaign season has presented broadcasters with a dilemma. Three demands of the Communications Act,

*Assistant professor, Ouachita Baptist University. 
though seemingly contradictory, became intertwined and created confusion as to precedence. First, candidates for federal elective office must be afforded air time. In addition, broadcasters may not censor the material produced by these candidates. When broadcasters were faced with problematic content in federal campaign advertisements, lawmakers, regulators and courts normally sided with the candidates.

However, a broadcaster's license may be revoked for broadcasting obscene, indecent or profane language. And in recent years, the Federal Communications Commission (FCC or the Commission), Congress and the courts have effectively broadened this concern to include material that could ostensibly be considered harmful to children. When several political campaign ads in 1992 and 1994 introduced unparalleled controversial content-the graphic depiction of aborted fetuses-broadcasters sought guidance and relief from the government.

Several candidates intentionally forced the issue by pitting the rights of the candidate against the responsibilities of the broadcaster. Milagros Rivera-Sanchez and Paul H. Gates, in tracing the history of indecency and political advertising, predicted that broadcasters would not need to fear sanctions from airing the pro-life candidates' advertisements. ${ }^{1}$ Seeking permission to channel the controversial material into late night/early morning hours may have only further diverted broadcasters from First Amendment objectives they ultimately desire.

This article begins with a review of the history behind controversial political advertising content. It then focuses on the attempts to restrict pro-life candidates' television content as a case study of how statutory and judicial decisions have attempted to provide a solution to a broadcasting anomaly. Specifically, this article considers the use of depictions of aborted fetuses in television advertisements and the efforts of broadcasters to restrict these ads. Finally, a call for a comprehensive review of the pertinent policies and issues is recommended.

The evolution of this broadcasting quandary took many years as questions were raised seriatum. What finally emerged is a twisted regulatory knot tied and retied by sometimes conflicting legislative, executive and judicial action. The results have alter-

\footnotetext{
${ }^{1}$ Milagros Rivera-Sanchez \& Paul H. Gates, Jr., Abortion on the Air: Broadcasters and Indecent Political Advertising, 46 FED. COMM. L.J. 267, 287 (1994).
} 
nated between binding and loosening the knot for both broadcasters and candidates for federal office.

\section{Political Advertising AND THe Communications ACT}

The statutes dealing with political broadcasting are found in Sections 312 and 315 of the Communications Act. Section 312 requires broadcasters to air material produced by candidates for federal office. It threatens revocation of a broadcaster's license for "willful or repeated failure to allow reasonable access to or to permit purchase of reasonable amounts of time for the use of a broadcasting station by a legally qualified candidate for federal elective office on behalf of his candidacy."2 The question of who legally qualifies as a candidate was answered by the FCC in 1978, i.e., such a person must (a) be eligible under law to hold the office if elected, (b) announce one's candidacy and (c) qualify for a place on the ballot or be eligible under law for election as a write-in candidate and make a "substantial showing." The constitutionality of reasonable access was answered by the Supreme Court of the United States in 1981. The Court ruled that once the campaign season begins, broadcasters "must give reasonable and good-faith attention to access requests from 'legally qualified' candidates for federal elective office."

Section 315 prohibits prior restraint by broadcasters of federal candidates' advertising content. ${ }^{5}$ The first case heard by the Supreme Court challenging this statute concerned content considered libelous. A radio station in North Dakota wanted to keep out references by the Farmers Educational and Cooperative Union of America concerning government officials. The announcer called them "Communists." The Court decided that censoring "allegedly libelous remarks would undermine the basic purpose for which Section 315 was passed-full and unrestricted discussion of political issues by legally qualified candidates." ${ }^{6}$ Thus, broadcasters could not censor content, but they also would not be held accountable for the content. ${ }^{7}$

\footnotetext{
${ }^{2} 47$ U.S.C. $\$ 312(a)(7)(1994)$.

${ }^{3}$ The Law of Political Broadcasting and Cablecasting, 69 F.C.C.2d 2209, 22162217 (1978).

${ }^{4}$ CBS, Inc. v. FCC, 453 U.S. 367,387 (1981).

${ }^{5} 47$ U.S.C. $\S 315$ (a) (1994) ("provided, that such licensee shall have no power of censorship over the material broadcast under the provisions of this section").

${ }^{6}$ Farmers Educational and Cooperative Union v. WDAY, Inc., 360 U.S. 525, 529 (1959).

${ }^{7}$ Political Broadcasting and Cablecasting, 69 F.C.C.2d at 2220.
} 
Later challenges concerned inflammatory language. In 1972, the National Association for the Advancement of Colored People (NAACP) requested that the FCC allow broadcasters to reject political advertisements that contained the word "nigger." The candidate, J.B. Stoner, sought a seat in the U.S. Senate. In its request, the NAACP indicated some broadcasters had received bomb threats, and it was the stations' responsibility to avoid these ads. The FCC found no evidence of the threats and, citing the WDAY decision, refused to grant the request. ${ }^{8}$

In 1978, the. Supreme Court's Pacifica decision upheld the constitutionality of restricting the broadcasting of indecent and obscene material. ${ }^{9}$ The NAACP returned to the FCC with its request that the word "nigger" be prevented from being broadcast, now based on the Pacifica. ${ }^{10}$ In its response, the Commission said the word did not fall under its definition of indecency, a definition upheld by the Court. ${ }^{11}$ Even if it were found indecent, however, Section 315 and Section $326^{12}$ would have prohibited broadcasters from preventing a candidate's use of the word in a television ad. ${ }^{13}$

In 1980, employees at NBC Radio initially refused to air a commercial for presidential candidate Barry Commoner of the Citizens Party. The advertisement included one of the seven words ruled indecent by the FCC and the Supreme Court in Pacifica. The network's attorneys advised NBC to air the advertisement in its entirety, which it did. Nevertheless, Commoner subsequently lodged a complaint with the FCC that NBC's initial refusal had violated Section 315. The Commission warned NBC to make its staff aware that there could be no censorship of political ads, even those containing offensive language. ${ }^{14}$

In 1984, the first indication that broadcasters might restrict the content of political advertising arose. Hustler magazine publisher

\footnotetext{
${ }^{8}$ Atlanta NAACP, 36 F.C.C.2d 635 (1972).

${ }^{9}$ FCC v. Pacifica Foundation, 438 U.S. 726 (1978).

${ }^{10}$ Julian Bond, NAACP, 69 F.C.C.2d 943 (1978) (Broadcast Bureau).

${ }^{11}$ FCC v. Pacifica Foundation, 438 U.S. at 944 (upholding FCC decision declaring seven words recorded by comedian George Carlin and aired on WBAI-FM, New York, to be indecent).

${ }^{12} 47$ U.S.C. $\$ 326$ (1994) ("Nothing in this Act shall be understood or construed to give the Commission the power of censorship ..., and no regulation or condition shall be promulgated or fixed by the Commission which shall interfere with the right of free speech by means of radio communication.").

${ }^{13}$ Julian Bond, 69 F.C.C.2d at 944.

${ }^{14}$ Barry Commoner and LaDonna Harris, 87 F.C.C.2d 1 (1980).
} 
Larry Flynt announced his intention to run for president by buying advertising in newspapers around the United States. He also declared his plans to challenge obscenity laws by showing "X-rated presidential campaign commercials" featuring "hard-core sex acts. ${ }^{15}$ Flynt later withdrew from the race, but not before the issue drew responses from several quarters. When members of Congress were told by FCC general counsel Bruce Fein that, indeed, broadcasters would be presented with a dilemma, Rep. Thomas A. Luken made it known that he planned to announce legislation banning "obscene" language. ${ }^{16}$ Then the FCC published a memorandum stating its position that broadcasters did not have to air obscenities.

\begin{abstract}
A broadcaster would be justified in refusing access to a candidate who intended to utter obscene or indecent language, because Section 312(a)(6) ... must be granted to carve an exception to Section $312(a)(7) . .$. The application of both traditional norms of statutory construction as well as an analysis of the legislative evolution of Section 315 militate in favor or [sic] reading section 1464 as an exception to Section $315 .{ }^{17}$
\end{abstract}

In a subsequent letter to Luken, FCC Chair Mark Fowler also broached the idea that a broadcaster's responsibility under Section 1464 of the U.S. Criminal Code ${ }^{18}$ supersedes Sections 315(a) and Section 312(a)(7) of the Communications Act. ${ }^{19}$ The contents of these statements by the Commission would help broadcasters' arguments

\footnotetext{
${ }^{15}$ Martin Schram \& James R. Dickenson, Political Notes, WASH. PoST, Dec. 2, 1983, at A3.

${ }^{16}$ The Supreme Court defined obscenity in Miller v. California, 413 U.S. 15, 24 (1973), using a threefold test: (a) whether the average person, applying contemporary community standards, would find that the work, taken as a whole, appeals to the prurient interest, (b) whether the work depicts or describes, in a patently offensive way, sexual conduct specifically defined by the applicable state law, and (c) whether the work, taken as a whole, lacks serious literary, artistic, political or scientific value. Obscenity is distinguished from the prohibition on indecent content applied to broadcasters. See FCC v. Pacifica Foundation, 438 U.S. 726 (1978).

${ }^{17}$ FCC Staff Memorandum, Jan. 6, 1984, quoted in Gillett Commun. of Atlanta, Inc. v. Becker, 807 F. Supp. 757, 762 (N.D. Ga. 1992), appeal dismissed without op., 5 F.3d 1500 (11th Cir. 1993) (emphasis in original).

${ }^{18} 18$ U.S.C. $\$ 1464$ (1994) (making illegal broadcast of "obscene" or "indecent" material).

${ }^{19}$ Letter from Mark S. Fowler to Hon. Thomas A. Luken, January 19, 1984, construed in Vincent Pepper, 7 F.C.C.R. 5599, 5600 (1992) (Mass Media Bureau).
} 
in 1992 to restrict candidates' advertisements using graphic pictures of aborted fetuses.

\section{THE REgulation OF INDECENCY}

While the Communications Act forbids the FCC from exercising prior restraint of broadcasts, ${ }^{20}$ the Commission may revoke a broadcaster's license for airing indecent material. ${ }^{21}$ The Commission relies on Section 1464 of the United States Criminal Code, which declared that "whoever utters any obscene, indecent, or profane language by means of radio communication shall be fined not more than $\$ 10,000$ or imprisoned not more than two years, or both." ${ }^{22}$ In 1987, the FCC determined that focusing on the seven Pacifica words was an insufficient standard by which to enforce indecency prohibitions. ${ }^{23}$ Instead, it proposed using the generic definition it had stated in its response to the complaint against WBAI-FM, i.e., "language or material that depicts or describes, in terms patently offensive as measured by contemporary community standards for the broadcast medium, sexual or excretory activities or organs." ${ }^{24}$

The Commission also reaffirmed that the time of day when material is broadcast may be a factor in determining whether it is indecent. Part of the FCC's Pacifica test concerned

${ }^{20} 47$ U.S.C.A. $\$ 326$ (West 1995).

${ }^{21} 47$ U.S.C.A $\S 312(a)(6)$ (West 1995).

${ }^{22} 18$ U.S.C. $\$ 1464$ (1994).

${ }^{23}$ Several complaints were brought to the FCC, including Infinity Broadcasting Corporation of Pennsylvania, 2 F.C.C.R. 2726, 2727, recon. denied, 3 F.C.C.R. 930 (1987) (station found to have broadcast on several occasions programming that "dwelt on sexual and excretory matters in a pandering and titillating fashion that was patently offensive as measured by contemporary community standards for the broadcast medium"); Pacifica Foundation, Inc., id. (licensee KPFK-FM, Los Angeles, had broadcast two programs found indecent, i.e., "IMRU" included "explicit descriptions of sexual encounters," and "Shocktime U.S.A." contained "certain expletives that one member of a local performing group made on a live program"); Regents of the University of California, $i d$. (student radio station cited because "the music broadcast contained a number of patently offensive references to sexual organs and activities as measured by contemporary community standards for the broadcast medium").

${ }^{24} \mathrm{New}$ Indecency Enforcement Standards to be Applied to all Broadcast and Amateur Radio Licensees, 2 F.C.C.R. 2726, 2726 (1987). 
a reasonable risk that children may be in the audience, but (the FCC) found that this benchmark is not susceptible to a uniform standard. ... The Commission further stated that indecent broadcasts could be made at times when there is not a reasonable risk that children may be in the audience and that, when such broadcasts were made, advance warnings would continue to be required.... The Commission concluded that, in order to limit children's access to such material on radio and television, time channeling is a reasonable time, place and manner restriction. ${ }^{25}$

WBAI-FM had broadcast the program during a weekday afternoon. The FCC adopted time channeling, or moving programs to a "safe harbor," as a compromise between concerns about indecency and broadcasters' First Amendment rights. The exact time of day when indecent programming would be permitted was challenged in several court cases. In 1988, 1991 and 1993, the United States Court of Appeals for the District of Columbia Circuit thwarted efforts by the FCC and by Congress to implement various safe harbor periods.

In the first case, filed by several broadcasters and public interest groups, the plaintiffs challenged the Commission's new policy concerning indecency, and asked that the prohibition of indecent programming from 6 a.m. to midnight be ruled unconstitutional. The Court of Appeals denied the first complaint (deferring to Supreme Court precedent), but found that the FCC had no basis for the 18-hour ban, and called for further Commission hearings and study. $^{26}$

Before the FCC could act, Congress, in passing its annual appropriation for the Commission, included the Helms Adult Radio Amendment. It called on the FCC to enforce the indecency section of the United States Code on a 24 -hour basis. ${ }^{27}$ Challenged in court, the District of Columbia Circuit found the complete ban unconstitutional. ${ }^{28}$ Again, the FCC was told to conduct hearings on the safe

\footnotetext{
${ }^{25} \mathrm{Id}$.

${ }^{26}$ Action for Children's Television v. FCC, 852 F.2d 1332 (D.C. Cir. 1988), overruled in part, 58 F.3d 654 (D.C. Cir. 1995).

${ }^{27}$ Departments of Commerce, Justice and State, the Judicial and Related Agencies Appropriation Act of 1989, Pub. L. No. 100-459, § 608, 102 Stat. 2186, 2228 (1988).

${ }^{28}$ Action for Children's Television v. FCC, 932 F.2d 1504 (D.C. Cir. 1991), cert, denied, 503 U.S. 913 (1992), overruled in part, Action for Children's Television v. FCC, 58 F.3d 654 (D.C. Cir. 1995).
} 
harbor question, and justify its choice of a time when indecent material could be broadcast. ${ }^{29}$

Once again, Congress stepped between the FCC and the courts. In the Public Telecommunications Act of 1992, the Commission was required to institute the 6 a.m. to midnight ban on indecency in addition to the midnight to $6 \mathrm{a} . \mathrm{m}$. ban already in place, effectively requiring a complete ban on broadcasting indecent material. ${ }^{30}$ When this provision reached the District of Columbia Circuit, the court, relying on its first decision on this issue, struck down the safe harbor mandate. It later vacated the decision for rehearing by the full Circuit Court of Appeals. ${ }^{31}$ A requirement that indecent material be channeled to the period from 10 p.m. to 6 a.m. was upheld in June $1995^{32}$

\section{Decisions on Pro-Life Candidates' Commercials}

In 1992 several candidates for congressional seats across the country added a new dimension to the troika of political advertising, indecency and channeling. About a dozen candidates produced and aired television advertisements that included footage of aborted fetuses, allegedly the result of third-trimester abortions. ${ }^{33}$ The first to do so, and arguably the most successful, was Michael Bailey who ran for the Indiana House seat occupied by Rep. Lee Hamilton. Bailey won the Republican primary, but in the general election, Hamilton received 70 percent of the vote. ${ }^{34}$ Only one other candidate using commercials showing aborted fetuses, Daniel Becker running in Georgia, made it past the primary election.

The fetus pictures in Bailey's advertisements came from a 1991 documentary produced by American Portrait Films of Cleveland. Some critics questioned whether the fetuses were aborted or the

\footnotetext{
${ }^{29} I d$. at $1509-1510$.

${ }^{30}$ Public Telecommunications Act of 1992, Pub. L. No. 102-356, § 16, 106 Stat. 949 (1992).

${ }^{31}$ Action for Children's Television v. FCC, 11 F.3d 170 (D.C. Cir. 1993), rehearing en banc denied, vacated, 15 F.3d 186 (D.C. Cir. 1994), petition granted, remanded, 58 F.3d 654 (D.C. Cir. 1995).

${ }^{32}$ Action for Children's Television v. FCC, 58 F.3d 654.

${ }^{33}$ Keith Glover, Campaigning Crusaders Air Graphic Anti-Abortion Ads, CoNG. Q., Sept. 26, 1992, at 2970. D1.

${ }^{34}$ Jason Vest, Campaigner in the Pit Bull Pulpit, WASH. POST, Feb. 27, 1993, at
} 
result of stillbirths. At least one other candidate also aired photographs that were considered "sexually explicit." Bailey and the other candidates agreed the footage was "repulsive" but necessary. At least one candidate's spots began with a warning: "This commercial is not suitable for small children, because abortion is not suitable for America." ${ }^{36}$ Some ads compared abortion with the Holocaust. $^{37}$

The television advertisements brought complaints to television stations, which led to requests for an FCC ruling on the ads. Two stations covering Indiana's 9th Congressional District, located in Indianapolis and Louisville, Kentucky, asked their attorneys to determine their options. The stations were told that Section $312(a)(7)$ required them to air the ads and that Section 315(a) prohibited censoring the content. ${ }^{38}$ The stations responded by airing editorials opposing the spots. ${ }^{39}$

In Georgia, the other primary winner using pictures of fetuses, Daniel Becker, faced opposition from Atlanta television stations. During the July Fourth holiday, Becker had purchased air time during Atlanta Braves baseball games on WTBS. ${ }^{40}$ Station executives did not want to air the ads and, after doing so based on their interpretation of FCC rules, reported hundreds of complaints. They were told by Diane Hofbauer, special assistant to the FCC general counsel, that "while these things may be gross and upsetting, it doesn't sound like they fall into the category of obscene."41

Later that month, Becker asked another Atlanta television station, WAGA-TV, to air a political advertisement. The station owner, Gillett Communications of Atlanta, Inc., joined by a Washington, D.C., law firm representing several unnamed radio and television stations, filed with the FCC a petition for a declaratory

\footnotetext{
${ }^{35} \mathrm{Glover}$, supra note 33 , at 2972.

${ }^{36}$ William Booth, Antiabortion TV Ads Catch On in Campaigns, WASH. PosT, July 20, 1992, at A1.

${ }^{37}$ Keith Glover, Bailey's Bailiwick, CoNG. Q., Sept. 26, 1992, at 2971.

${ }^{38}$ Joe Flint, Furor Over Anti-Abortion PoliticalAds, BroADCASTING, Apr. 27, 1992 , at $41-42$.

${ }^{39} I d$. at 41 .

${ }^{40}$ Although TBS is a superstation reaching many cable outlets across the country, the advertisements were shown only to the local Atlanta audience of WTBS-TV. See Kathy Scruggs, Candidate Won't Pull Graphic Abortion Ads, ATL. Journal \& CoNST., July 5, 1992, at A10.

${ }^{41}$ Booth, supra note 36 , at $\mathrm{A} 7$.
} 
ruling. Instead of calling the material obscene, the petition asked the Commission to concur with Gillett that ads "featuring dead fetuses and fetal tissue depict excretory activities and are therefore indecent." ${ }^{\prime 2}$ Because of this, Gillett wanted to channel the ads to a time of day when children were less likely to be watching. This would be consistent, the petition read, with the reasonable access and noncensorship provisions of the Communications Act. ${ }^{43}$

The co-petitioner, the law firm Kaye, Scholer, Fierman, Hays and Handler (Kaye Scholer), went further and requested that the "entire class of programming 'containing graphic and shocking depictions of dead, bloodied or aborted fetuses or any other similar graphic and shocking depictions of excised or bloody fetal tissue" 44 be deemed indecent. Kaye Scholer added that even if the Commission disagreed with the comparison of fetal tissue with excretory activity, the FCC should defer to individual stations the judgment of determining what is indecent and therefore worthy of being restricted to certain times of day. ${ }^{45}$

In his response, FCC Mass Media Bureau Chief Roy Stewart made several determinations. First, he declined to rule that any depiction of fetal tissue or dead fetuses was indecent. He added that rendering a ruling in advance of a broadcast would impose prior restraint on protected speech. Stewart also took issue with the desire to restrict a candidate's access to prime time. This, Stewart said, would deprive the candidate of his right to determine how to run his campaign. Further, Stewart wrote that upon review of a videotape submitted by Gillett, the Bureau's conclusion was that the content was not indecent, nor did the material constitute excretory activity as the term was used in the FCC's indecency policy. ${ }^{46}$

\section{THE BECKER DECISION}

As the 1992 campaign neared its close, congressional candidate Becker approached WAGA-TV in Atlanta asking to air a half-hour advertisement following the broadcast of a professional football

\footnotetext{
${ }^{42}$ Letter from Roy Stewart, Chief, FCC Mass Media Bureau, to Vincent A. Pepper, Counsel, Gillett Communications, 7 F.C.C.R. 5599, 5599 (1992).

${ }^{43} I d$. at 5600 .

${ }^{44} I d$. at 5599 .

${ }^{45} \mathrm{Id}$.

${ }^{46} I d$. at 5600.
} 
game on the Sunday afternoon prior to Tuesday's election. Gillett, representing WAGA, filed suit against both Becker and the FCC in federal district court, seeking an injunction against the ad and a declaration regarding indecent political advertising. ${ }^{47}$

The court's ruling effectively reversed the decision contained in Stewart's letter. ${ }^{48}$ The court held that prohibiting indecent material was a valid exception to the reasonable access, equal opportunities and no-censorship regulations of the Communications Act. ${ }^{49}$ The court also ruled the material in Becker's program to be indecent. The half-hour program included a segment titled "Abortion in America: The Real Story," which contained pictures not found in Becker's earlier advertisements. This material, according to the court, showed "graphic depictions and descriptions of female ger italia, the uterus, excreted uterine fluid, dismembered fetal body parts, and aborted fetuses. ${ }^{50}$ In addition, citing Action for Children's Television $v . F C C,{ }^{51}$ the court found the material indecent to the extent that children readily could understand it.

The impact on children was compelling enough to warrant government involvement, said the court, because the government had an interest in "safeguarding the physical and psychological well-being of a minor." ${ }^{52}$ Noting that the FCC had not ruled on this material, the court found that this video was more graphic and four times longer than seen in Becker's previous advertisement. ${ }^{53}$ Consequently, WAGA's offer to air the program between midnight and 6 a.m. would benefit the plaintiff and the public interest (protecting children from indecent material) without inflicting undue injury on Becker. Finally, the court acknowledged that under normal circumstances, it would have allowed the FCC to decide the issue, and questioned the court's authority to enjoin the activities of the Com-

${ }^{47}$ John Harmon, Anti-abortion Ad Rattles TV Station, ATL. JOURNAL \& CONST., Oct. 29,1992 , at E4.

${ }^{48}$ See supra text accompanying notes $42-46$.

${ }^{49}$ Gillett Commun. of Atlanta, Inc. v. Becker, 807 F. Supp. 757, 757-758 (N.D. Ga. 1992), dismissed without op., remanded, 5 F.3d 1500 (11th Cir. 1993).

${ }^{50} I d$. at 763 .

${ }^{51} 852$ F.2d 1332, 1340 (D.C. Cir. 1988), overruled in part, 58 F.3d 654 (D.C. Cir. 1995).

${ }^{52}$ Gillett Commun. v. Becker, 807 F. Supp. at 764 (quoting New York v. Ferber, 458 U.S. 747, 756-57 (1982)).

${ }^{53}$ Gillett Commun. v. Becker, 807 F. Supp. at 764. 
mission. ${ }^{54}$ A day after the district court's decision, a federal appeals court dismissed Becker's appeal. ${ }^{55}$ Five days later Supreme Court Justice Anthony Kennedy declined to hear an emergency appeal from Becker. ${ }^{56}$

The FCC's Mass Media Bureau sent a letter to Becker, dated the same day as the initial court decision. ${ }^{57}$ The candidate had asked for intervention by the FCC to grant him access to the television station. Bureau chief Stewart informed the candidate of the Commission's unwillingness to render a decision before a program was broadcast. Instead, Stewart invoked the 1984 staff memo and letter to Rep. Luken to warn Becker that the staff believed it would not be unreasonable

for the licensee to rely on the informal staff opinion referred to above and conclude that Section 312(a)(7) does not require it to air, outside the "safe harbor," material it reasonably and in good faith believes is indecent. ${ }^{58}$

That same day the FCC issued a Public Notice, calling for comments on the issue of channeling material that presents depictions of dead or aborted fetuses. ${ }^{59}$ The Commission requested comments on whether broadcasters have the right or obligation to channel political advertisements that are indecent, and material that may be otherwise harmful to children.

\section{INDECENCY AND HARM TO CHLDREN}

A coalition of broadcasters and interest groups responded to the Commission's call for comments. ${ }^{60}$ The coalition called on the Com-

\footnotetext{
${ }^{54} I d$.

${ }^{55}$ Gillett Commun. of Atlanta, Inc. v. Becker, 807 F. Supp. 757, dismissed without op., remanded, 5 F.3d 1500.

${ }^{56}$ Rebecca Perl, High Court Lets TV Block Abortion Ad, But Candidate Can Seek Late-Night Airtime, ATL. JourNAL \& Const., Nov. 2, 1992, at B2.

${ }^{57}$ Letter from Roy J. Stewart, Chief, FCC Mass Media Bureau, to Daniel Becker, 7 F.C.C.R. $7282(1992)$.

${ }^{58}$ Id. at 7283 .

${ }^{59}$ Section $312(a)(7)$ of the Communications Act, 7 F.C.C.R. 7297 (1992).

${ }^{60}$ The coalition included the National Association of Broadcasters, the Association of Independent Television Stations, Fox Television, Capital Cities/ABC, NBC, the Public Broadcasting Service and the Radio Television News Directors Association. See Harry A. Jessell, Broadcasters Oppose Widening Indecency Net, BroADCASTING, Feb. 1, 1993, at 54.
} 
mission to allow broadcasters editorial control, letting them decide what is indecent material or inappropriate for their audiences. They argued broadening the definition of indecency would threaten "to encompass news, informational and series dramatic programming on a variety of topics." ${ }^{" 1}$ Gillett Communications added that broadcasters should be able to reject entirely any offensive material that "the station would otherwise reject as not in the public interest." 62

Daniel Becker argued that broadcasters should not decide what is indecent. "It would be too easy for a broadcaster to censor an unpopular political message under the guise that the message was indecent." ${ }^{63}$ Joining Becker against channeling were the National Right to Life Committee and the American Civil Liberties Union. They argued that graphic abortion imagery did not constitute indecent political advertising content, and that expanding the indecency definition would "constitute a serious constitutional infringement by interfering with First Amendment protection of news and entertainment programming." There was also concern about channeling material deemed not indecent but nonetheless "harmful to children." Political speech, it was argued, qualified as "super-protected speech" and should be protected against any discrimination on the basis of political ideas. ${ }^{66}$

The FCC did not release a ruling on the matter until after the November 1994 election. That Memorandum Opinion and Order noted that the majority of letters the FCC received strongly opposed broadcasting depictions of abortion during times when children were likely to be viewing. The Commission determined that political ads that included "graphic abortion imagery" did not constitute indecency. ${ }^{67}$ But, citing both its Codification of Political Programming Policies and the Communications Act, the FCC recognized that circumstances might require a broadcaster to "reasonably refuse broadcast time to political candidates during certain parts of the day." 68

${ }^{61} I d$.

${ }^{62}$ Section 312(a)(7) of the Communications Act, 9 F.C.C.R. 7638, 7641 (1994).

${ }^{63} \mathrm{Jessell}$, supra note 60.

${ }^{64}$ Section 312(a)(7), 9 F.C.C.R. at 7640.

${ }^{65} I d$.

${ }^{6} I d$. at 7641.

${ }^{67} I d$. at 7639, n.3. The Commission noted its disagreement with the district court's ruling, believing that Judge Hall had erroneously applied the indecency standard. Id. at 7644 n.12.

${ }^{68} \mathrm{Id}$. at $7645 \mathrm{n} .14$ (citing Codification of the Commission's Political Programming Policies, 7 F.C.C.R. 678, 682 (1991), quoting Commission Policy in Enforcing Section 312 (a)(7) of the Communications Act, 68 F.C.C.2d 1079, 1091 (1978)). 
In the Opinion and Order, the FCC suggested that Congress, in mandating through Section $312(\mathrm{a})(7)$ that federal candidates must be given broadcast time, surely had not intended to prevent broadcasters from exercising discretion to consider the impact on children in the audience. ${ }^{69}$ Lastly, the Commission prefaced its decision by noting that candidates do not have a First Amendment right of access to air time; rather, the question turns on the First Amendment right of viewers to have access to political speech. ${ }^{70}$ Although not indecent, the depiction of dead fetuses could warrant a licensee's decision to channel a political ad containing such material to a time when children are less likely to be watching, without transgressing earlier conditions of the Communications Act.

Earlier in 1994, Michael Bailey had asked television stations to air advertisements during the congressional campaign of an Ohio candidate. ${ }^{71}$ The commercials contained photographs of dead fetuses, but some also contained "scenes from gay pride marches including footage of leather-clad men grinding pelvises and kissing each other." ${ }^{72}$ After Bailey filed a complaint with the FCC in response to a Cincinnati station's attempt to restrict the advertisements to late night time periods (after 12:30 a.m.), the station carried the advertisements during morning programming.

\section{CONCLUSION}

When he learned that his advertisements on Atlanta television stations could be restricted to safe harbor hours, Daniel Becker responded: "Live births, actual murders and dead bodies are shown during prime time, but abortion shows must be viewed along with pornography and other filth from midnight to 6 a.m." ${ }^{, 73}$ Government in recent years has handed down various judgments broadening the definition of indecency, banning or channeling indecent material, and most recently applying the term "indecent" to heretofore protected political speech. These decisions invite challenge.

\footnotetext{
${ }^{69} I d$. at 7646 n.16.

${ }^{70} \mathrm{Id}$, at 7648 .

${ }^{71}$ Christopher Stern, Antiabortion Ads Resurface at FCC, BroadCASTING \& CABLE, Apr. 18, 1994, at 36.

${ }^{72}$ Vest, supra note 34 , at D8.

${ }^{73}$ Perl, supra note 56 , at B3.
} 
Candidate Bailey warned that "this is just the beginning. The country hasn't seen anything yet." The content of several Bailey commercials suggested the possibility of future clashes. Are there some political and social ideas that when visualized become untenable to the viewing public, except during the hours when most of the country has turned off their television sets? No candidate would concede that channeling political statements accommodates his or her interests.

When the FCC released its 1994 Memorandum Opinion and Order, it took the opportunity to rectify the "indecency" error in the district court's Becker decision. The Commission determined that "aborted fetuses or fetal tissue, alone, cannot be considered 'excretory by-products' within the meaning of the indecency definition." Doing so would expand the definition far beyond its limit. Yet the Commission did see fit to override statutory law by allowing some restrictions within Section 315 .

Either political campaign advertisements (as political speech) are a form of super-protected speech, ${ }^{76}$ and are thus untouchable, or Sections 312(a)(7) and 315(a) should be reconsidered. Political speech during campaigns by legally qualified candidates has traditionally been considered separately from other forms of programming. But the FCC has also carved out loopholes for segregating ideas and platforms to certain- segments of the day, even as it champions a wide array of access for federal candidates. ${ }^{77}$

Precedents are few for responding to the offensive, outrageous or indecent political ad. There are references in Commission decisions to a 1984 memorandum by FCC staff ${ }^{78}$ and a letter from a Commission chair to a United States representative ${ }^{79}$ suggesting

\footnotetext{
${ }^{74}$ Vest, supra note 34.

${ }^{75}$ Section 312(a)(7) of the Communications Act, 9 F.C.C.R. 7638, 7643 (1994).

${ }^{76}$ See T. Barton Carter, Marc A. Franklin \& JaY B. Wright, The First AMENDMENT AND THE FIFTH ESTATE 34-35 (1993).

${ }^{77}$ Commission Policy in Enforcing Section 312(a)(7) of the Communications Act, 68 F.C.C.2d 1079, 1091 (1978). See also Codification of the Commission's Political Programming Policies, 7 F.C.C.R. 678, 682 (1991).

${ }^{78}$ FCC Staff Memorandum, Jan. 6, 1984, quoted in Gillett Commun. of Atlanta, Inc. v. Becker, 807 F. Supp. 757, 762 (N.D. Ga. 1992), appeal dismissed without op., 5 F.3d 1500 (11th Cir. 1993).

${ }^{79}$ Letter from Mark S. Fowler to Hon. Thomas A. Luken, January 19, 1984, cited in Vincent Pepper, 7 F.C.C.R. 5599, 5600 (1992) (Mass Media Bureau).
} 
that a broadcaster could be justified in interpreting Section 1464 of the federal Criminal Code as an exception to Section 315. The FCC has also justified regulation of broadcast indecency as support for parental supervision of children and the protection of the family against offensive broadcast material. ${ }^{80}$ This suggests that legal scholars and the Commission should undertake additional study of what political advertisements may be restricted before broadcasters will be able to determine the acceptable limits.

The outline established by the courts and commission hinges on the interpretation of "harm to children." In the Becker decision, District Court Judge Robert Hall recognized that his ruling rested on the First Amendment requirement that "a content-based restriction on speech, especially political speech, must be 'a precisely drawn means of serving compelling state interest' to withstand constitutional scrutiny." ${ }^{\prime 1}$ His decision reflected the view that "safeguarding the physical and psychological well-being of minors" superseded the public right to have access to political speech. ${ }^{82}$ The Commission has stated that broadcasters may balance First Amendment considerations against potential "harm[ ] to children" by "graphic abortion imagery." Neither decision included empirical evidence of viewing by or harm to children. When one concept-indecency - was unable to solve the problem, another was substituted.

The Commission has carved out a ruling independent of both indecency precedents and political speech requirements. Broadcasters were handed editorial control of content previously untouchable. It remains to be seen if graphic abortion imagery is to be singled out. However, the door is now open to revisit earlier decisions. If Congress once gave broadcasters an unreasonable mandate to accommodate all legally qualified candidates for federal office, the FCC has now altered that mandate. Protecting children is a justification for restricting the ads of candidates promoting their pro-life beliefs with controversial content. As candidate Bailey commented during his first campaign, he could not get his commercials carried on television before declaring for federal office; becoming a congres-

\footnotetext{
${ }^{80}$ See, e.g., Enforcement of Prohibitions Against Broadcast Indecency in 18 U.S.C. $\S 1464,5$ F.C.C.R. 5297 (1990).

${ }^{81}$ Gillett Commun. v. Becker, 807 F. Supp. 757, 764 (citing Action for Children's Television v. FCC, 852 F.2d, 1332, 1343 n. 18 (D.C. Cir. 1988)).

${ }^{82}$ Gillett Commun. of Atlanta, Inc. v. Becker, 807 F. Supp. at 764.

${ }^{83}$ Section $312(a)(7)$ of the Communications Act, 9 F.C.C.R. 7638, 7647 (1994).
} 
sional candidate was his only recourse. ${ }^{84}$ The appropriateness of Section 312(a)(7) is a legitimate concern, but for now those candidates with advertisements containing material some consider shocking and offensive may learn that their ads will be found by the Commission and courts to be harmful to children.

Some political advertising content, while legal, will be considered inappropriate for broadcast during times when children are in the audience. Broadcasters may now draw some lines warranted by potential harm to children. They may not have to worry about FCC sanctions for disregarding Section 312(a)(7) of the Communications Act under certain circumstances. But challenges will arise because there will be candidates attempting to cross the blurry line.

There have been enough attempts to strengthen, tighten and reinforce the political broadcast advertising "knot" in piecemeal fashion so as to thoroughly tangle and fray the metaphorical rope. Rather than wait for the next controversial political issue or continue to use past decisions on new media, ${ }^{85}$ it is time for a complete reassessment of the need for mandatory political advertising time on broadcast channels, the concepts of indecency and safe harbors, the notion of harm to children, broadcasters' First Amendment rights and the citizen's right to know. Each has been alternately inserted into or excluded from arguments to fit a particular philosophical or political perspective.

Putting the issue in a First Amendment context, several questions cast doubt on the wisdom of many of the decisions, regulations and statutes. One tenet of freedom of speech is self-governance. Meiklejohn maintained that the First Amendment forbade Congress from abridging the freedom of speech whenever it was utilized for the governing of the nation. This included even obscene content because it has a "social importance." 86

It may be harmful for children to view broadcast depictions of the results of an abortion, or it may just be unsettling. But that alone should by no means be the standard by which channeling is recommended. The issue is a serious one for advocates of both positions

\footnotetext{
${ }^{84}$ Vest, supra note 34 , at D8.

${ }^{85}$ Congress began addressing indecent programming content on cable and via the Internet in 1995. See Christopher Stern, Senate Mandates TV Ratings System, BROADCASTING \& CABLE, June 19, 1995, at 12.

${ }^{86}$ AleXANDER MEIKLEJOHN, The First Amendment Is an ABsolute 246, 255 (Cynthia Brown ed., Meiklejohn Civil Liberties Institute 1981)(1961).
} 
and deserves as broad a platform for discussion as possible. As long as broadcasters are required to acquiesce to the political demands of federal candidates, the ban on censorship should remain intact. Ironically, the broadcast media's attempts to limit the expression of one political position may have driven them further from the rights they feel the Constitution should afford them. 